\title{
Development of Functional Academic Guidebook Based on Experiential Learning for Teacher Specialized in Teaching Children with Intellectual Disability
}

\author{
Yeni Irma NORMAWATI ${ }^{1}$, Ishartiwi ISHARTIWI, ${ }^{2}$ Mumpuniarti MUMPUNIARTI ${ }^{3}$ Sayidatul \\ MASLAHAH $^{4}$
}

\section{ARTICLE INFO}

Article History:

Received 25.09.2019

Received in revised form

10.11.2020

Accepted

Available online 01.01.2021

\begin{abstract}
This study is to determine the feasibility of functional academic guidebook based on experiential learning model in terms of material and media aspects. The type of research is research and development $(\mathrm{RnD})$, using Borg and Gall model. The procedure for developing teaching materials is limited to 9 steps of activities, namely: research and information collecting, planning, preliminary form of product development, preliminary field testing, main product revision, main field testing, operational product revision, operational field testing, and final product testing. The research subjects were 6 special school teachers. The eligibility of teaching material product is validated by a material expert and a media expert. Data collection used is a questionnaire and interview. Based on the results of the study, the feasibility of a functional academic guide book based on the validation of the material experts is 3.37 (very good) and the media experts is 3.74 (very good), the results of main field testing is 3.18 (very good), and operational field testing is 3.51 (very good).
\end{abstract}

(C) IJERE. All rights reserved

Keywords:

Functional academic guidebook, experiential learning, teacher, children with intellectual disability.

\section{INTRODUCTION}

Teaching material is material used to assist teachers in carrying out learning activities. Learning as a process of behavior change in cognitive, affective, and psychomotor aspects. The change is through the process of interacting with the material. The learning process cannot be separated from the use of teaching materials that play a role to achieve the competencies that must be achieved by the students (Rini, Suryani, \& Fadhilah : 2019). The material developed by the teacher should refer to the curriculum or be contained in the syllabus whose delivery is tailored to the needs and environment of students(Syah : 2007). The preparation of teaching materials also needs to be adjusted to the conditions of the students. Students who were the target of this study were mild retarded children. Children with intellectual disability are weak in conceptual, so the substance of teaching materials needs to be directed at functional skills.

According to Mumpuniarti \& Pujaningsih (2016) learning functional skills requires support from the academic field, one of which is mathematics. The ten basic areas of mathematics included in the curriculum include: problem solving, the use of mathematics for everyday situations, determining estimates, calculating skills accurately, geometry and measurement, reading symbols and interpreting, constructing tables, charts and graphs, using mathematics to production, as well as computer readability. These ten basic areas of mathematics are often found in functional academic curricula. Bouck and Joshi (2012) define functional academics as an approach that teaches students the skills to help them become productive members of society, able to empower themselves according to their abilities after they graduate from the bench. Judging from the needs and importance of functional academic mastery by children with mild intellectual disabilities, functional academic learning in this study will be focused on functional mathematics subjects with basic competencies in the ability to use money used in daily activities, known as money skills).

This ability to count is important to be mastered by children with mild intellectual disability. It is very important for someone to understand the importance of being able to complete monetary transactions and make purchases with the correct amount of money independently (Allen, 2016). Children with mild intellectual disability if they have mastered money skills, they will not experience mistakes when dealing with buying and selling transactions. According to the results of fourth grade teacher interviews at elementary school level, the obstacle experienced by children with mild intellectual disability in money skills

\footnotetext{
${ }^{1}$ Corresponding e-mail: yeninormawati01@gmail.com, https://orcid.org/0000-0001-9834-5231

${ }^{2}$ Corresponding e-mail : ishartiwi@uny.ac.id, https://orcid.org/0000-0001-7881-5547

Corresponding e-mail: mumpuni@uny.ac.id, https://orcid.org/0000-0001-8063-7957

4Corresponding e-mail : sayidatulmaslahah2@gmail.com , https://orcid.org/0000-0003-4179-4567

Students of Special Education Major at Universitas Negeri Yogyakarta ${ }^{14}$

Lecturers of Special Education Major at Universitas Negeri Yogyakarta ${ }^{23}$
} 
is in the case of arithmetic operations, namely addition and subtraction when shopping or paying for certain transactions. On the other hand they cannot estimate how much money must be paid, or money that must be received (Normawati, Mumpuniarti, and Ishartiwi : 2019).

Based on observations at two special schools in Yogyakarta, the development of money skills teaching materials for children with mild intellectual disability has not been found. On the other hand, the school is equipped with a canteen that can be used as a device that supports the learning process. Therefore, researchers are interested in developing teaching materials in the form of handbooks for implementing experiential learning for teachers in teaching money skills to their students (Normawati, Mumpuniarti, and Ishartiwi : 2019). Experiential learning is learning through direct experience in the context of real life. The experiential learning model invites students to play an active role during the learning process by developing student experiences (Nurhasanah, Malik, Nurhayatin: 2017). This functional mathematics learning about money can be carried out in a real context in the school environment, by utilizing the school canteen.

This experiential learning model will help improve the spirit of learning because children with intellectual disability are actively involved in real experiences. This can develop the thought process because they are involved in doing something to build knowledge. This is in accordance with the experiential learning stage, namely the concrete experience stage where at this stage a person experiences an event as it is (Kolb and Kolb: 1999).

\section{Aim of the Study}

The purpose of this study was to determine the feasibility of functional academic teaching materials based on experiential learning in terms of material and media aspects.

\section{METHOD}

This study is research and development (RnD). According to Borg and Gall (2007), they state "Educational Research and Development $(\mathrm{RnD})$ is a process used to develop and validate educational products". In this study, the development model follows the Borg and Gall stages, which will be limited to 9 out of 10 steps including research and information collecting, planning, preliminary form of product development, preliminary field testing, main product revision, main field testing, operational product revision, operational field testing, and final product testing. The research subjects who tested the functional academic teaching material products were 6 teachers.

Table 1. The Sample Features of The Research

\begin{tabular}{ccccc}
\hline No & Name & Gender & Ethnicity & School \\
\hline $\mathbf{1}$ & AAP & Male & Javanese & SLB Tunasbakti \\
$\mathbf{2}$ & SR & Female & Javenese & SLB Tunasbakti \\
$\mathbf{3}$ & VS & Female & Javenese & SLB Tunasbakti \\
$\mathbf{4}$ & IR & Female & Javanese & SLB Yapenas \\
$\mathbf{5}$ & YN & Female & Javanese & SLB Yapenas \\
$\mathbf{6}$ & RY & Female & Javanese & SLB Yapenas \\
\hline
\end{tabular}

Data collection techniques in this study consisted of interviews and questionnaires. Both of these data collection techniques are used according to the needs and stages of the development procedure. When analyzing product needs, researchers use interviews with teachers to conduct preliminary studies. Whereas during the product development process, researchers used a questionnaire to determine product viability.

Data analysis technique in this research is quantitative data analysis technique. The result data from this research is in the form of responses from media experts and material experts on the quality of the products that have been developed in terms of various aspects being assessed. Data in the form of scores of responses from media experts and material experts obtained through questionnaires were analyzed by 
looking for an average rating between two or more ratings. Obtaining an average score of each component of the assessment aspects using the formula:

$$
X=\frac{\sum x}{\mathrm{~N}}
$$

Information :

$X=$ average score

$\sum x=$ total score $\quad N=$ number of assessors

Furthermore, all data that has been obtained on each item then added up is called the actual score (X). The actual quantitative score is converted to a qualitative value by referring to the conversion of the score into a scale of 4 . The reference for changing the score to a scale of 4 can be seen in Table 1 .

Table 2. Convert Scores to Score Scores 4 (Mardapi : 2008)

\begin{tabular}{|c|c|c|c|}
\hline Number & Interval scores & Grades & Categories \\
\hline 1 & $\mathrm{X}>\overline{\mathrm{X}}+1 . \mathrm{SBx}$ & A & Very good \\
\hline 2 & $\overline{\mathrm{X}}+1 . \mathrm{SBx}>\mathrm{X} \geq \mathrm{X}$ & B & Good \\
\hline 3 & $\mathrm{X}>\mathrm{X} \geq \overline{\mathrm{X}}-1 . \mathrm{SBx}$ & C & Fair \\
\hline 4 & $\mathrm{X}<\overline{\mathrm{X}}-1 . \mathrm{SBx}$ & $\mathrm{D}$ & Poor \\
\hline
\end{tabular}

The value of product feasibility in this study will be determined with a minimum value of "B" with either category. So, if the results of the evaluation by the validator give a minimum final result of "B" then the product development of this teaching material is worth using.

\section{RESULT}

\section{Research and Information Collecting}

The research began with a preliminary study conducted in April 2019 in two special schools in Yogyakarta. Based on observations and interviews, the teacher revealed a number of things:

a. The importance of functional academic mastery in basic competencies about money skills for children with mild intellectual disability. Children with mild intellectual disability have difficulty's thinking in abstract terms so learning strategies must be implemented more through real-life practice and experience.

b. Development of functional academic teaching materials for children with mild intellectual disability is still lacking. Teachers in teaching use Curriculum 2013 textbooks.

c. The development of functional academic teaching materials is needed by teachers because so far the source of functional academic books is limited. Teaching materials should be arranged according to students' abilities, arranged from easy to difficult and can be applied in daily life (practical).

\section{Planning}

This stage consists of product design and product manufacture. Product design and manufacturing is based on needs in the field, namely the need for teaching materials that can be used in functional academic learning. This is done as follows. 
a. Creating a storyboard that is making a descriptive brief description that contains the path that will exist in the learning product starting from the beginning of the description and introduction to the concept of up to assessment.

b. The process of developing teaching materials uses a set of tools used, including image processing software (Corel draw 7), and word processing software (Microsoft Word). Broadly speaking, the product of the teaching material resulting from the initial stage of development contains the following.

1. The identity of the book, containing the title of teaching material, the identity of the author, the logo of the college and the logo of the Ministry of Research, Technology and Higher Education that has funded this research.

2. Preface, containing gratitude and intention of writing teaching material by the author.

3. Introduction, contains a brief description of functional mathematics learning about the concept of money and its relation to experiential learning models.

4. Target of teaching materials.

5. How to use instructional materials containing teacher guides to learn the contents of the material appropriately.

6. The concept map of teaching materials contains the scope of material developed in teaching materials.

7. Unit 1 contains functional academic concepts

8. Unit 2 contains concepts of children with mild intellectual disability.

9. Unit 3 contains the experiential learning learning model

10. Unit 4 contains the determination of material, strategies, and learning outcomes in experiential learning

11. Unit 5 contains examples of functional mathematics learning based on experiential learning

12. Bibliography

\section{Development Preliminary Form of Product}

The following is the initial design of teaching material products before making improvements and after being given advice by the supervisor.

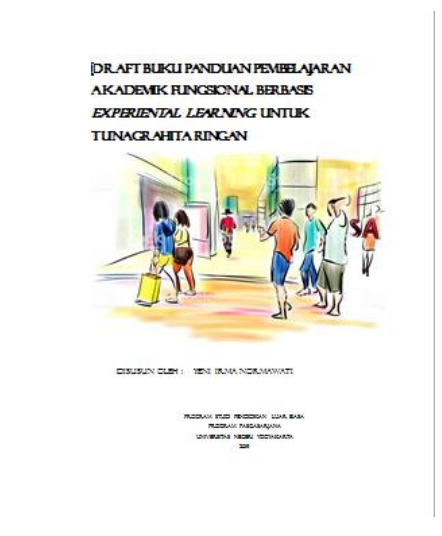

Initial cover product

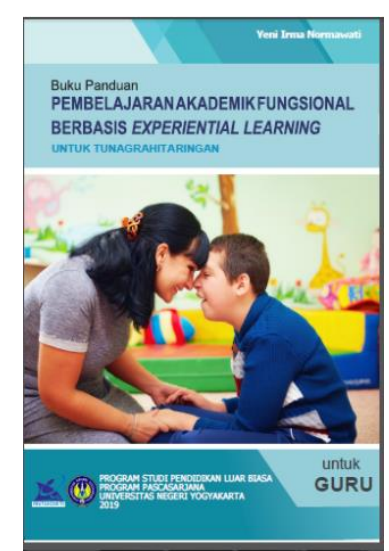

supervisor

Improvement on the advice of the

Figure 1. Improvement of teaching material cover

Based on figure 1, repairs are made on the book cover. Before repairing, the book cover was still designed using Microsoft Word with a simple design, without giving the background color to the text. After repairs, the cover is designed using the Corel Draw 7 application with a background color, the title of the text is made larger, using a real image, and using variety of fonts and font sizes. 


\section{Preliminary Field Testing}

\section{a. Media Expert Data Description}

Media validation was carried out by Educational Technology lecturer ( Sungkono, M.Pd.) at Universitas Negeri Yogyakarta (UNY) on 11 and 18 September 2019. Considerations on choosing a validator are: (1) Mr. Sungkono, M.Pd. teaches the development of teaching materials in the Department of Educational Technology and has written a book about teaching material development. The aspects assessed in the instrument validation are aspects of language, aspects of graphics, aspects of quality and size of teaching materials, and the feasibility of presentation.

Validation is done by providing a product of teaching materials resulting from the development to be further assessed by filling out a questionnaire on a scale of 4 . The validation process of media experts is carried out twice. Although the first validation shows results in very good categories, however, it cannot yet be used for teaching. Teaching materials can be used after the second validation process with very good categories. The results of the assessment of media experts can be seen in the following table.

Table 3. Results of media expert validation

\begin{tabular}{llcccc}
\cline { 2 - 5 } No & $\begin{array}{l}\text { Assessment } \\
\text { aspects }\end{array}$ & Assessment I & Assessment II & Average & Category \\
\cline { 2 - 6 } 1 & Language suitability & 3,60 & 3,80 & 3,70 & Very good \\
\cline { 2 - 6 } 2 & 3,70 & 3,80 & 3,75 & Very good \\
\cline { 2 - 6 } 3 & Grafting & 4,00 & 4,00 & Very good \\
\cline { 2 - 6 } & $\begin{array}{l}\text { The quality and size } \\
\text { of teaching materials }\end{array}$ & & & & \\
\cline { 2 - 6 } 4 & $\begin{array}{l}\text { Feasibility of } \\
\text { presentation }\end{array}$ & 3,50 & 3,50 & 3,50 & Very good \\
\hline & & & 3,74 & Very good \\
\hline
\end{tabular}

The assessment of teaching material products from media experts commented that this teaching material can provide new knowledge for teachers in teaching functional academics by using experiential learning. As for the advice of media experts, namely: the systematic presentation of the contents of the guide needs to be considered again, the preparation of colors, fonts, need to be reconsidered, and illustrations are better to use their own pictures.

\section{b. Material expert data description}

Material validation was conducted by Special Education lecturer (Dr. Hermanto, M.Pd.) at Universitas Negeri Yogyakarta. Validation was conducted twice on October 16 and 25, 2019. The aspects assessed are: the suitability of the material, the feasibility of the presentation, the suitability of the language, graphics, and experiential learning models. Validation is done by providing the product of teaching materials that are developed and then given an assessment by filling out a scale 4 questionnaire.

The first validation results show the results in the excellent category, but cannot be used for research. Teaching materials can be used after the second validation process with very good categories. The results of expert material assessment can be seen in the following table 
Table 4. Result of material expert validation

\begin{tabular}{lcccc}
\hline \multicolumn{1}{c}{ Assessement aspect } & Assessment I & Assessment II & Average & Category \\
\hline Material suitability & 3,25 & 3,75 & 3,50 & Very good \\
& & & 3,25 & Very good \\
\hline Feasibility of presentation & 3,00 & 3,50 & 3,37 & Very good \\
& & & & \\
\hline Language suitability & 3,00 & 3,75 & 3,50 & Very good \\
\hline Grafting & 3,25 & 3,75 & 3,25 & Very good \\
\hline $\begin{array}{l}\text { Application of experiential } \\
\text { learning }\end{array}$ & 2,75 & 3,75 & & \\
\hline Average & & & 3,37 & Very good
\end{tabular}

The assessment of teaching material products from the material experts commented that if the teaching material is in the form of a teacher's manual, work sheets must also be prepared for students, it can be in the form of a student worksheet or book.

\section{Main Product Revision}

The revision of teaching material products is carried out in accordance with the suggestions and comments of the validator. Suggestions include: improved concept maps, experiential learning steps are clarified again, and the word 'syntax' experiential learning is replaced by experiential learning components.

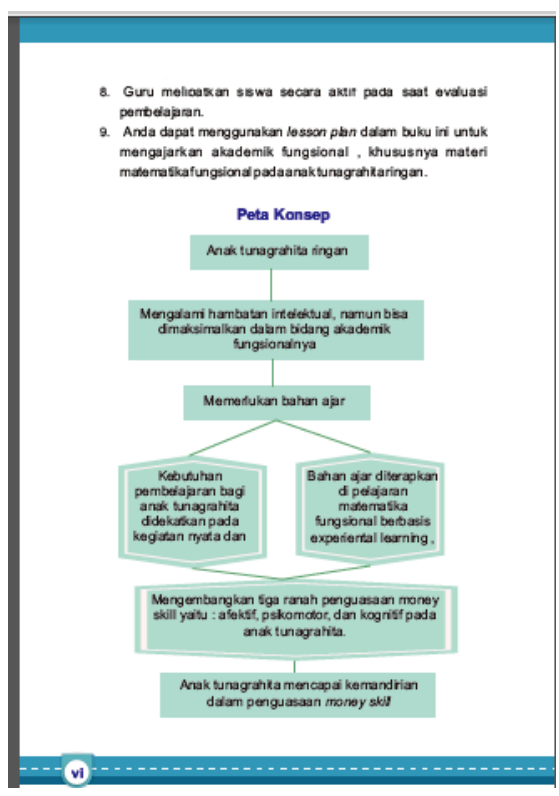

Initial product

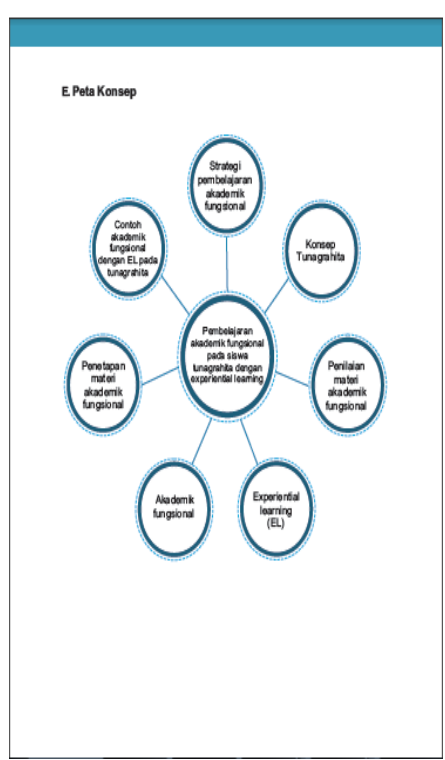

Improvement of concept map 


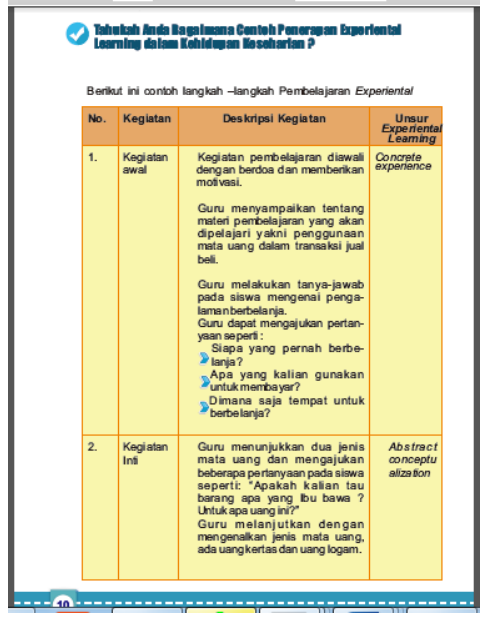

Initial product

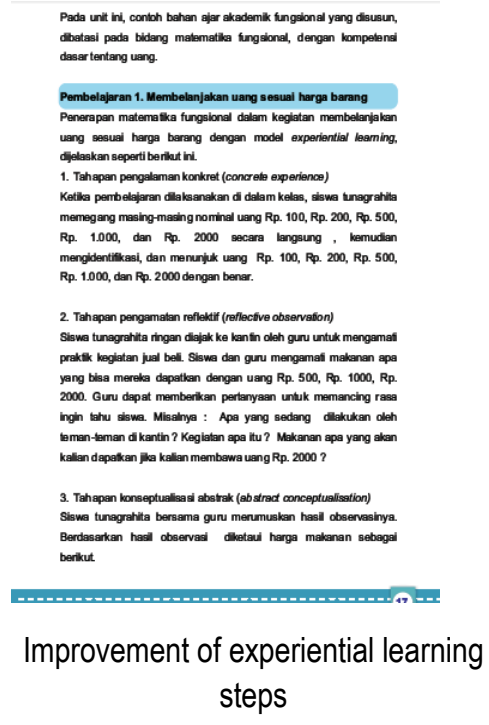

Figure 3. main product revision

In figure 2, repairs are made in 3 parts. First improvement on the concept map section. The original concept map that was compiled looked more like a mindset. The second fix on the yellow background is striking. The choice of color is changed to white, because it is adjusted for users as adults. Improvements to the steps are also more adapted to the concepts of each component of experiential learning. The third improvement, the word "syntax" is replaced by steps. The word "syntax" is unfamiliar to the teacher.

\section{Main Field Testing}

The trial was conducted on October 15-17, 2019 at SLB Tunas Bhakti on 3 teachers. The trial was conducted by giving teaching material products to teachers to read and then the products were assessed by filling in the assessment sheets of the aspects of content, the feasibility of presentation, linguistic, graphic, application of experiential learning models, and user convenience. Overall assessment of teaching materials products get 3.18 results on a scale of 4 with a very good category, with suggestions for improvement. The results of the assessment in the initial field trials can be seen in the following table.

Table 5. Main Field Testing Result

\begin{tabular}{clcll}
\hline No & Assessment aspect & $\begin{array}{l}\text { Total } \\
\text { score }\end{array}$ & $\begin{array}{l}\text { Average } \\
\text { of three } \\
\text { subjects }\end{array}$ & Category \\
\hline 1 & Content & 24 & 2,67 & Good \\
\hline 2 & Feasibility of presentation & 27 & 3,00 & Good \\
\hline 3 & Linguistic & & & \\
\hline 4 & Grafting & 37 & 3,08 & Very Good \\
\hline 5 & $\begin{array}{l}\text { Application of experiential } \\
\text { learning model }\end{array}$ & 36 & 3,00 & Very Good \\
\hline 6 & Ease of use & 19 & 3,00 & Good \\
\hline & Average & & 3,17 & Good \\
\hline
\end{tabular}

Based on the data of the results of the 3 teacher trials, the overall assessment obtained an average score of 3.18 with a very good category meaning the media is feasible to be implemented. Based on the 
results of the teacher's assessment of teaching materials, the teacher provides suggestions for improvement for researchers. The advice given by the teacher is as follows.

(a) The evaluation sheet is less focused on the intended use of the book.

(b) Characteristics of students who will be taught functional academics are unclear.

(c) The manual should be completed with worksheets to be worked on by students.

(d) Functional mathematical examples are clarified again because there are only a small scope in the book.

\section{Operational Product Revision}

The revision of teaching material products is carried out in accordance with the suggestions and comments from validator. Suggestions include: improved concept maps, experiential learning steps are clarified again, and the word 'syntax' experiential learning is replaced by components of experiential learning.

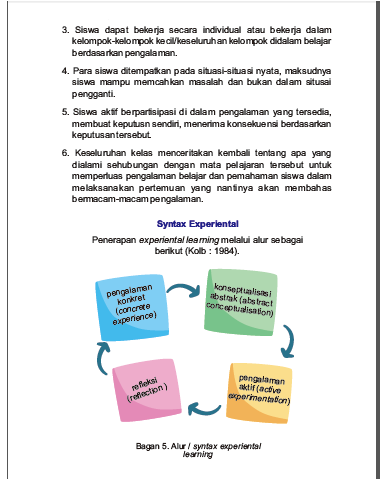

Initial product

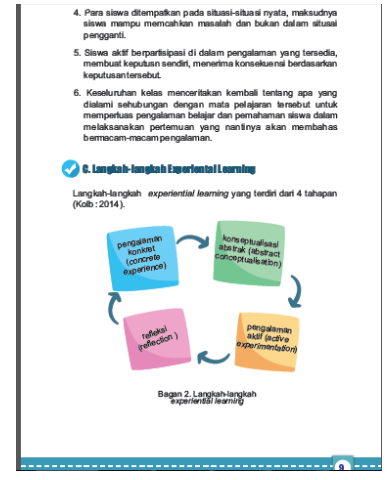

Improvement of the word syntax into experiential learning steps

Figure 4. Operational product revision

In figure 4, repairs are made in 3 parts. First improvement on the concept map section. The original concept map that was compiled looked more like a mindset. The second fix on the yellow background is striking. The choice of color is changed to white, because it is adjusted for users as adults. Improvements to the steps are also more adapted to the concepts of each component of experiential learning. The third improvement, the word "syntax" is replaced by steps. The word "syntax" is unfamiliar to the teacher.

\section{Operational Field Testing}

The trial was conducted on October 23-25, 2019 on the subject of 6 special school teachers. The trial was conducted by giving teaching material products to the teacher to then be assessed by filling in the assessment sheets in terms of content aspects, presentation eligibility, language, graphics, application of experiential learning models, and user convenience. The product evaluation in the main field trial phase obtained a score of 3.51 on a scale of 4 with very good categories for the aspects of content, feasibility of presentation, linguistic, graphic, application of experiential learning models, and user convenience. Good category is obtained from grammar aspects, information clarity and EYD suitability. The results of the assessment in the main field trials can be seen in the following table. 
Table 6. Result of Operational Field Testing

\begin{tabular}{|c|c|c|c|c|}
\hline No & Assessment aspect & Total score & $\begin{array}{l}\text { Average of } 6 \\
\text { subjects }\end{array}$ & Category \\
\hline 1 & Content & 57 & 3,17 & Very good \\
\hline 2 & Feasibility of presentation & 65 & 3,61 & Very good \\
\hline 3 & Linguistic & 80 & 3,33 & Very good \\
\hline 4 & Grafting & 94 & 3,92 & Very good \\
\hline 5 & $\begin{array}{l}\text { Application of experiential } \\
\text { learning model }\end{array}$ & 83 & 3,46 & Very good \\
\hline \multirow[t]{2}{*}{6} & Ease of use & 42 & 3,50 & Very good \\
\hline & Total & 421 & 20,99 & Very good \\
\hline & Average & & 3,51 & \\
\hline
\end{tabular}

Based on the results of the 6 teacher trial data, the overall assessment obtained an average score of 3.51 with a very good category meaning the media is feasible to be implemented. Based on the main field trials, the teacher provides comments and suggestions for product improvement. As for the positive comments on the product developed, the teacher feels helped by the functional academic guide book based on experiential learning because it implements other learning methods in teaching the concept of money to mild retarded students. In addition to positive comments, the teacher provides suggestions for products developed as follows: (a) font fonts must be consistent, (b) fonts can use several colors to display important parts, (c) assessment rubrics are clearly made.

\section{Final Product Revision}

Suggestions for improvement given by teachers, so that teaching materials are equipped with learning tools such as the design of learning programs.

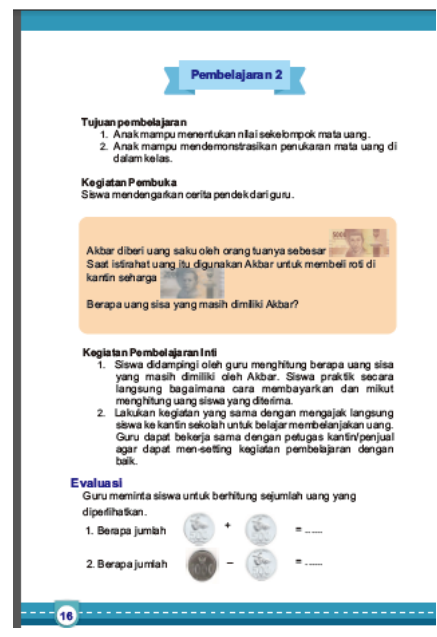

Initial product

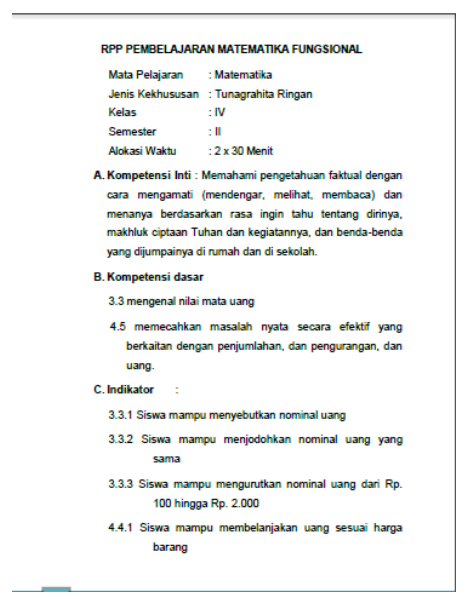

The product is equipped with a learning program design

Figure 5. Completeness improvements 


\section{DISCUSSION}

Functional academics are academic learning that is functioned more in daily life. Fields studied in functional academics include reading, writing, arithmetic, science and social studies (Polloway, Patton, Serna, and Bailey: 2013). Students with mild intellectual disabilities in mastering this functional academic need special assistance, such as instruction from special education teachers, special techniques or strategies to make it easier for them to access learning (Lewis and Doorlag, 2011).

The functional academic field is an important thing that must be mastered by children with intellectual disability. This field is used when students are deemed to need assistance in the area of life skills, and when the educational experience received by students in schools through the general education curriculum is less appropriate in pursuing the skills needed for the success of post-school students. (Bouck, 2004; Retish, Hitchings, Horvath, \& Schmalle, 1991).

Functional academic material compiled in this guidebook is focused on functional mathematics with basic competencies about money. Money skills are very important for managing households, paying bills, and engaging in recreational activities, including other daily living activities that require money to participate (Rowe and Test, 2012). Individuals with mild intellectual disabilities often do not have control over their own finances because of a lack of skills, opportunities, or both (Newman, et al: 2011). Important money counting skills are mastered by mild retarded students as provision for their survival in the community as independent community members (Waters and Boon, 2011). However, problems found related to the ability to count money for students with mild intellectual disabilities often indicate deficits in the field of money counting (Waters and Boon, 2011).

This functional academic guide is based on experiential learning theory. Through experiential learning theory it is known that the concept of learning as a process of how knowledge is created through forms of experience (Kolb, Boyatzis, and Mainemalis, 1999). Therefore, the learning activities arranged are brought close to the daily experience for students.

This experiential learning model activates the learning process to build knowledge and skills through hands-on experience (Sholihah, Utaya, and Susilo: 2017). This model will be meaningful if students participate in carrying out activities (Silberman: 2015). Students are actively guided by the teacher to find their own or build their own knowledge through direct activities that he feels. For example through the role playing method, the practice of shopping directly in the canteen, and see videos about saving.

Teaching using role-playing is a holistic teaching method that instills critical thinking processes, influences emotions and moral values, and informs about factual data (Bhattacharjee: 2014). Thus, students with intellectual disabilities can feel a real picture of something that is being learned. Good teachers will try to ensure students can connect what they do at school with daily experiences and the real world outside the classroom (Cockburn and Handscomb, 2006: 227).

Pierce and Middendorf's research also found that teaching with role-playing methods increases the efficacy of the learning experience and makes it more real in reality (Pierce and Middendorf: 2008). The results of other studies indicate that students will be more successful in mastering learning material if directly involved in real situations. One learning model that can be used by teachers in bringing reality closer to learning is the experiential learning method.

The development of this functional academic teaching material uses the Borg \& Gall model. The first stage is analyzing the need to explore the potential and problems that are in the field. Researchers conducted interviews with teachers at SLB Tunas Bhakti. Based on the results of the interviews, information was obtained that the development of functional academic instructional materials for the concept of money did not yet exist. Teachers in teaching functional academic material concepts of money, use textbooks from the government.

The results of the analysis of student and teacher's book content on functional academics, on the basic competencies of the concept of money, the compiled learning materials seem to highlight more the academic 
realm, the affective and psychomotor domains less indicated in the student book. Lack of learning resources for the 2013 Curriculum book, according to the teacher, the learning materials compiled are still uniformed so that they are sometimes not in accordance with students' abilities.

Aspects that need to be considered by teachers in developing teaching materials should be to recognize the characteristics of users, the compatibility between learning objectives, learning materials, and their evaluation. So the teaching material that should be developed meets certain criteria. The criteria for good teaching materials according to Widodo and Jasmadi (2008) are (1) the feasibility of the contents, (2) the feasibility of linguistic aspects, (3) the feasibility of presentation and (4) the feasibility of graphics.

The assessment of the material experts gave a score of 3.37 in the excellent category. The feasibility of the content of the presentation of teaching materials is given very good value because the presentation of systematic material, in accordance with the stages of learning in experiential learning theory. This is in accordance with the eligibility criteria for the content of teaching materials according to Widodo (2008), Suparman (2014: 321) and Harjanto (2011: 222).

Media experts gave an assessment of 3.51 with Very Good criteria. Ratings from media experts score high on competency wrinkles in teaching material despite suggestions for improvement. A map of the content of teaching materials and subcompetencies is displayed on one page so that the reader can look more clearly. This is in accordance with the statement of Suparman (2014: 187) that writing competencies to the subcompetencies section which is a general part and compiling subcompetencies in a logical order list.

The quality of the content of teaching materials has a very good feasibility because it includes the objectives of teaching materials, how to use teaching materials, competencies that are used appropriately, complete material content and in accordance with the needs of students students with mild intellectual disabilities who need extra practical guidance. Teaching needs for students with mild intellectual disabilities will often intersect with giving prompt, additional instruction, and providing practical guidance (Lewis and Doorlag, 2011: 217). The feasibility of the quality of the contents and objectives is in accordance with the eligibility criteria for the content of teaching materials according to Widodo (2008), Suparman (2014: 321), and Harjanto (2011: 222).

\section{CONCLUSION}

Based on the results, the feasibility of a functional academic guidebook based on the validation of material experts is 3.37 (very good) and media experts is 3.74 (very good), the results of the main field testing was 3.18 (very good), and the operational field testing was 3.51 (very good).

Limitations of this study are the manuals prepared are limited for use in teaching students with mild intellectual disabilities. Other limitation, on this study the dissemination and implementation was not carried out due to limited costs. The suggestion for further research, functional academic teaching materials can be developed for students with intellectual disabilities using other learning methods or models and can also be developed for other special need children. In addition, this research can be followed up by doing experiment research using this guidebook.

\section{REFERENCES}

Allen, E.S. (2016). Financial skills for students with intellectual disabilities and autism. The Journal of Intellectual Disability Research, 49(3),210-217.

Bhattacharjee, S. (2016). Effectiveness of role-playing as a pedagogical approach in construction education. 50th ASC Annual International Conference Proceedings.

Bouck, E. C. (2004). State of curriculum for secondary students with mild mental impairment. Education and Training in Developmental Disabilities, 39, 169-176.

Bouck, E.C. \& Joshi, G. (2012). Functional curriculum and students with mild intellectual disability: Exploring postschool outcomes through NLTS2. Education and Training in Developmental Disabilities, 47, 139-153.

Cockburn, A. D. (2006). Teaching children 3 to 11 Second Edition. London : Paul Chapman Publishing. 
Gall, M., Gall, J., \& Borg, R. (2007). Educational research an introduction. Eight Edition. USA: Pearson.

Harjanto (2011). Perencanaan Pengajaran. Jakarta: Rineka Cipta.

Kolb, D. A., Boyatzis, R. E. \& Mainemelis, C. (1999). Experiential learning theory : Previous research and new direction. Project: Learning Sustainability, DOI: 10.4324/9781410605986-9.

Lewis, R.B \& Doorlag, D.H. (2011). Teaching student with special needs in general education classrooms. USA: Pearson.

Mardapi, D. (2008). Teknik Penyusunan Instrumen dan Nontes. Yogyakarta: Mitra Cendikia Offset.

Mumpuniarti \& Pujaningsih (2016). Pembelajaran Akademik Fungsional dalam Konteks Pendidikan Khusus Orientasi Budaya. Yogyakarta: UNY Press.

Newman, L., Wagner, M., Knokey, A.-M., Marder, C., Nagle, K., Shaver, D., \& Schwarting, M. (2011). The post-high school outcomes of young adults with disabilities up to 8 years after high school (A report from the National Longitudinal Transition Study-2 [NLTS2; NCSER 2011-3005]). Menlo Park, CA: SRI International.

Normawati, Y. I., Mumpuniarti \& Ishartiwi (2019). The need of functional academic learning resources for teacher in developing metacognition of student with intellectual disability. Proceedings of the 2nd International Seminar on Guidance and Counseling 2019 (ISGC 2019) volume 462.

Nurhasanah, S. Adam Malik, D. Mulhayatiah. (2017). Peneapan Model Experiental Learning untuk Meningkatkan Kemampuan Berpikir Kritis Siswa. Jurnal Wahana Pendidikan Fisika, 2(2),58-62.

Pierce, D., \& Middendorf, J. (2008). Evaluating the effectiveness of role playing in the sport management curriculum. International Journal of Sport Management and Marketing, 4(2), 277-294.

Polloway, E. A., Patton,J.A., Serna,L. \& Bailey,J.W. (2013). Strategies for teaching learners with special needs. USA: Pearson.

Retish, P., Hitchings, W., Horvath, M., \& Schmalle, B. (1991). Students with mild disabilities in the secondary school. New York: Longman.

Rini, A. P., Suryani, N. \& Fadhilah, S. S.. (2019). Development of the predict observe explain (Poe)-based thematic teaching materials. International Journal of Educational Research Review, 4(1),1-7.

Rowe, D. A., Test, D. W. (2012). Effects of simulation to teach students with disabilities basic finance skills. Journal of Remedial and Special Education,34(4)237-248. DOI: 10.1177/0741932512448218rase.sagepub.com.

Sholihah, M., Sugeng, U. \& Singgih, S. (2017). Pengaruh Model Experiental Leaarning terhadap Kemampuan Berpikir Siswa. Jurnal Pendidikan: Teori, Penelitian, dan Pengembangan,1(11), Bulan November Halaman: 2096-2100.

Suparman, A. (2014).Desain Instruksional Modern, Panduan Para Pengajar dan Inovator Pendidikan Edisi Keempat. Jakarta: Erlangga.

Waters, Hugh E. dan Boon, Richard T. (2011). Teaching money computation skills to high school students with mild intellectualdisabilities via the Touchmath@ Program: A multi-sensory approach. Journal of Education and Training in Autism and Developmental Disabilities, 46(4), 544-555.

Syah, D. (2007). Perencanaan Sistem Pengajaran Pendidikan Agama Islam. Jakarta: Gaung Persada Press, hal. 69

Widodo, C. (2008). Panduan Menyusun Bahan ajar Berbasis Kompetensi. Jakarta : PT. 